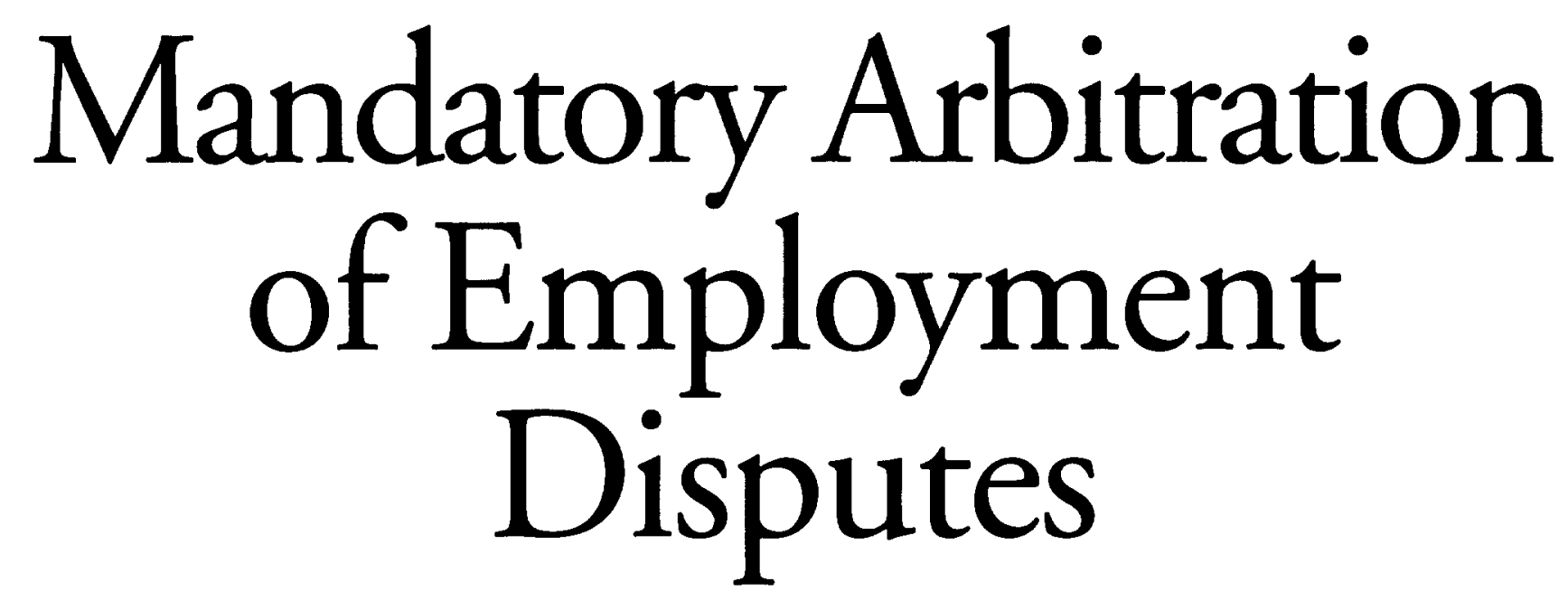

\title{
Implications for Policy and Practice
}

\section{In jurisdictions where mandatory-arbitration policies for employment disputes are enforceable, they can be a useful tool for employers and employees alike.}

\section{BY DAVID S. SHERWYN AND J. BRUCE TRACEY}

$\mathrm{T}$

The hospitality industry's increasingly diverse labor force and ongoing problems with employee turnover have created a breeding ground for claims of employment discrimination. The internal and external costs associated with such claims have convinced employers to examine the use of alternative dispute resolution (ADR) and, specifically, mandatory arbitration, to adjudicate employment-discrimination lawsuits. In a 1995 Cornell Quarterly article, Joseph I. Goldstein described the legal standing of ADR and discussed its positive aspects. ${ }^{1}$ While Goldstein's article introduced the

1 J.I. Goldstein, "Alternatives to High-cost Litigation," Cornell Hotel and Restaurant Administration Quarterly, Vol. 36, No. 1 (February 1995), pp. 28-33.

(ᄃ) 2001, CORNELL UNIVERSITY. This article previously appeared in the October 1997 issue of Cornell Quarterly. subject, it did not definitively state whether employers can, in fact, legally implement a mandatory ADR program (e.g., mandatory arbitration) or how employers might implement such a plan.

To address those issues, we first explain the problems with the current systems for settling claims of employment discrimination and argue that hospitality employers should consider mandatory arbitration as a means for resolving such disputes. $^{2}$ Second, we analyze the current law and identify

${ }^{2}$ It should be noted that this discussion focuses on nonunion employers. As we explain in this article, arbitration clauses in collective-bargaining agreements generally cannot prevent employees from filing discrimination claims. Also as explained here, an exception occurs in the Fourth Circuit Court of Appeals, but that case seemingly contradicts precedent from the U.S. Supreme Court and other circuits. 
jurisdictions where it is lawful for an employer to require employees to arbitrate discrimination claims. Finally, we discuss the issues that need to be examined to create and implement a lawful and well-received arbitration policy.

\section{Adjudication Is Expensive and Inefficient}

The many shortcomings to the current system of adjudicating employment disputes are explained at length in the sidebar discussion on pages 64 and 65 . In summary these shortcomings are as follows.

First, the Civil Rights Act of 1991 (among other developments) makes employmentdiscrimination claims attractive to plaintiffs by allowing jury trials and providing for punitive and compensatory damages. As a result, many claims that are filed today can be characterized as frivolous or nuisance complaints. Prior to 1991 damages typically consisted of reinstatement, back pay, and attorneys' fees and were mainly settled out of court or through the intervention of a government agency (such as the Equal Employment Opportunity Commission, or EEOC).

Second, settlements are larger than before despite the actual merits of the complaints. This is due in part to employers' concerns regarding the costs associated with dragging the dispute through the legal system.

Third, the current system of adjudication is essentially a de facto severance system-a process of setrling claims regardless of merit or validity. This is because it is simple for an employee to file a charge of discrimination and it is costly for an employer to defend against that charge. As a result, there is a strong incentive for employers to settle cases regardless of their merit.

Fourth, the system provides government investigators with a strong incentive to settle cases, also regardless of the cases' merits. For example, some agencies evaluate the investigators by how many cases they close each quarter, and it is standard procedure for some state investigators to attempt to settle a case without even discussing the case's merits or reviewing the file.

Fifth, claims are not being investigated in a timely or comprehensive manner. One reason for delay is that the increase in the number of cases filed has coincided with a decrease in the number of EEOC investigators.
Overall, the negative effects of the system on both hospitality firms and employees is evidenced by the increasing number of "no cause" determinations made by investigators (up from 28 percent in 1980 to 61 percent in 1992).

In sum, because of the amount of time and money it takes to investigate and prosecute or adjudicate a case, the current enforcement system is, according to one federal court judge, simply a "bad system for both the employer and the employee." In practice, however, we propose that the current system hurts only the good actorsemployees with legitimate claims and employers falsely accused of discrimination. Conversely, the system benefits the bad actors-employers who discriminate and employees who file frivolous claims.

We believe that there are ways to avoid the system's shortcomings. Specifically, mandatoryarbitration agreements, where enforceable, may be the most effective of those alternatives.

\section{Is Mandated Arbitration Legal?}

The law regarding whether an arbitration clause in an employment agreement can preclude the judicial adjudication of statutory rights (e.g., discrimination, wage and salary issues) is complex and unsettled. In almost every jurisdiction, however, a compulsory-arbitration policy will prevent nonunion employees from bringing a discrimi-

\section{The current system is essentially a de facto severance system-a process of settling discrimination claims regardless of merit.}

nation lawsuit into federal court. A union arbitration clause will nor have the same preclusive effect, except in the Fourth Circuit. ${ }^{4}$ To explain the specifics of the law, it is necessary to examine the two leading U.S. Supreme Court decisions, as well as several U.S Court of Appeals cases.

Text continues on page 63

${ }^{3}$ The Honorable James Moran, chief judge for the U.S. District Court, Northern District of Illinois, quoted in: Peter Eisler, "Waiting for Justice," USA Today, August 15, 1995, p. Al.

${ }^{4}$ See: Austin v. Owens Brockway Glass Container, 78 F.3d 875 (4th Cir. 1996). 


\section{A New Look at Arbitration}

In October 1997 Cornell Quarterly published the accompanying article discussing the legal and practical concerns surrounding arbitration of discrimination lawsuits. Four years later the issue remains relevant and has grown in importance. The following is an update of the law since the article was published four years ago.

\section{New Arbitration Holdings}

In 1997 we identified the applicability of the Federal Arbitration Act (FAA) as an issue that may determine whether an arbitration agreement is enforceable. The FAA endorses arbitration, but excludes from coverage employment contracts of employees engaged in foreign or interstate commerce. At the time, six circuits had interpreted the exception as applying only to employees in the transportation industry. Consequently, in those jurisdictions, employers outside the transportation industry were free to require employees to sign arbitration agreements. Four circuits, including the Ninth Circuit, had not ruled on the issue and one circuit, the Fourth, had held that the FAA was irrelevant.

In 1999 the Ninth Circuit finally weighed in on the issue.' Predictably, this court ruled against employers by holding that: (1) the FAA exception covered all employment contracts; and (2) that mandatory arbitration agreements were unenforceable because they did not fall under the FAA. In March 2001 the Supreme Court, in Circuit City Stores v. Adams, rejected the Ninth Circuit's holding and ruled that the FAA's exception was limited to the transportation industry. ${ }^{2}$ Many observers suggested that the Supreme Court's holding ended the controversy and essentially legalized mandatory arbitration. This, however, is not the case. Instead, there is another legal barrier to arbitration, and that is Section 118 of the Civil Rights Act of 1991.

Section 118 states, in part, that: "[w] here appropriate and to the extent authorized by law, the use of alternative dispute resolution, including.... arbitration, is encouraged to resolve disputes arising under [Title VII and the ADA]." In Duffield v. Robertson Stephens \& Co. the Ninth Circuit held that Section 118 prohibits mandatory arbitration (because it states that arbitration is "encouraged"). ${ }^{3}$ The First, Second, Third, Fourth, Fifth, Seventh, and District of Columbia circuits have rejected Duffield. ${ }^{4}$ Those courts held that Section 118 does not prohibit and may, in fact, allow mandatory arbitration, albeit the D.C. Circuit Court's language offered that conclusion only by strong implication. The remaining circuits have not yet ruled on the issue.

One California district court has held that the Supreme Court overturned Duffield in Circuit City. ${ }^{5} \mathrm{At}$ least two other district courts in the Ninth Circuit have rejected such an interpretation and held that Duffield is still good law. ${ }^{6}$ What this means is that at this time, mandatory arbitration is lawful in the First, Second, Third, Fourth, Fifth, Seventh, and D.C. circuits. While the law is unsettled in the Sixth, Eighth, Tenth, and Eleventh circuits, it is likely that those circuits will follow the majority by rejecting Duffield and upholding arbitration. What will happen to Duffield in the Ninth Circuit is anyone's guess. Regardless, we expect the Supreme Court to clarify this issue by overturning Duffield in the near future.

In addition to legal challenges, mandatory arbitration is still under attack from the EEOC (Equal Employment Opportunity Commission) and certain members of Congress (see the sidebar on page 64). Senator Russell Feingold (D-Wisconsin) and Representative Edward Markey (D-Massachusetts) have proposed legislation to overturn Circuit City and to prohibit mandatory arbitration. This legislation has been proposed since the early 1990 s and has not succeeded to date. We see no reason why that will change in the immediate future.

Since 1997 the law surrounding mandatory arbitration has been clarified with regard to the FAA, but has become muddied by Section 118. Still, the courts (except for the Ninth Circuit) have been favorable toward arbitration. This is a trend that we believe will continue.-J.B.T. and D.S.S.

\footnotetext{
${ }^{1}$ See: Craft v. Campbell Soup Co., 177 F.3d 1083 (1999).

${ }^{2} 121$ S. Ct. 1302 (2001)

${ }^{3} 144$ F.3d 1182 (9th Cir. 1998). See also: David Sherwyn, J. Bruce Tracey, and Zev Eigen, "In Defense of Mandatory Arbitration of Employment Disputes: Saving the Baby, Tossing Out the Bath Water, and Constucting a New Sink In the Process," Journal of Labor and Employment Law, University of Pennsylvania, Vol. 2, No. 1 (Spring 1999).
}

${ }_{4}^{4}$ First Circuit: Rosenberg v. Merrill Lynch, Pierce, Fenner of Smith, Inc., 170 F.3d 1 (1st Cir. 1999); Second Circuit: Desiderio v. NASD, 191 F.3d 198 (2nd Cir. 1999); Third Circuit: Seus v. John Nuveen \& Co., 146 F.3d 175 (3rd Cir. 1998); Fourth Circuit: Hooters of America, Inc. Philips, 173 F.3d 933 (4th Cir. 1999); Fifth Circuit: Mouton v. Metropolitan Life Ins. Co., 147 F.3d 453 (5th Cir. 1998); Seventh Circuit: Koveleski v. SBC Capital Markets, Inc., 167 F.3d 361 (7th Cir. 1999); and District of Columbia Circuit: Borg-Warner Protective Services Corp. $v$. United States EEOC, 245 F.3d 831 (D.C. Cir. 2001).

5 Olivares v. Hispanic Corp., 2001 U.S. Dist. Lexis 5760 (C.D. Cal. 2001).

${ }^{6}$ See: Melton v. Philip Morris, Inc., 2001 U.S. Dist. Lexis 12601 (D. Or. Aug. 9, 2001); and LeLouis v. Western Directory Co., 2001 U.S. Dist. Lexis 1251 (D. Or. 2001). 
In Alexander v. Gardner-Denver Company, the Supreme Court held that an arbitration clause in a collective-bargaining agreement does not bar a union employee from litigating a Title VII discrimination case in federal court, even if the employee had already sought arbitration and lost the decision. ${ }^{5}$ For a time lower courts extended this holding to nonunion work environments, so that compulsory-arbitration clauses could not prevent any employee, union or nonunion, from litigating any right protected by antidiscrimination statutes.

Then, in Gilmer v. Interstate-Johnson Lane Corporation, the Supreme Court distinguished its Gardner-Denver decision and held that a compulsory-arbitration clause could after all prevent a nonunion employee from filing an agediscrimination claim in federal court. ${ }^{6}$ (See the sidebar at right for the court's reasoning.) Among its arguments the court pointed out that, unlike the Gardner-Denver case, the arbitration clause in Gilmer's employment contract was enforceable under the Federal Arbitration Act of 1925 (FAA). ${ }^{7}$

\section{An Irrelevant Law?}

The FAA "reflects a liberal policy of favoring arbitration," the court wrote. ${ }^{8}$ This statute requires the enforcement of arbitration awards, establishes a limited standard of review, and develops procedures for the selection of arbitrators, among other things. Section 2 of the FAA states that the act applies to all contracts affecting commerce. Section 1 of the FAA, however, excludes from coverage "all contracts of employment of seamen, railroad employees, or any other classification of workers engaged in foreign or interstate commerce."

In Gilmer the arbitration clause was enforceable under the FAA because the contract was not between the employee and the employer, but was instead between the employee and the New York Stock Exchange. This distinction allowed the

s Alexander v. Gardner-Denver Company, 415 U.S. 36 (1974).

${ }^{6}$ Gilmer v. Interstate-Johnson Lane Corporation, 111 S.Ct. 1647 (1991).

79 U.S.C. Section 1.

${ }^{8}$ Gilmer, at 1657.

\section{Union versus Nonunion Work}

\section{Environments}

In Gilmer v. Interstate-Johnson Lane Corporation the U.S. Supreme Court held that a compulsory-arbitration clause could prevent a nonunion employee from filing an age-discrimination claim in federal court. ${ }^{1}$ The specific facts of this case are as follows. To gain employment, Gilmer, the plaintiff (a registered securities representative), signed the New York Stock Exchange's securities registration application. The application contained a compulsory-arbitration clause. On being terminated from his position with his employer, the plaintiff filed an Age Discrimination in Employment Act (ADEA) lawsuit in federal court. The court held that the arbitration clause was enforceable and barred the plaintiff from filing an age-discrimination suit in federal court. Subsequent to that Gilmer decision, lower courts extended the holding to alleged violations of Title VII of the Civil Rights Act of 1964.

The Supreme Court's holding in Gilmer may seem to be at odds with that of Alexander v. Gardner-Denver Company, in which the Supreme Court held that an arbitration clause in a collective-bargaining agreement does not bar a union employee from litigating a Title VII discrimination case in federal court. ${ }^{2}$

The Gilmer court distinguished its holding from that in Gardner-Denver for three reasons. First, because a labor arbitrator's role is limited to enforcing the parties' collective-bargaining agreement, the arbitrator in Gardner-Denver did not have the authority to determine whether the discrimination law had been violated. Second, the Gilmer court noted that the GardnerDenver arbitrator's task was to "effectuate the best interests of the parties," even if those interests were in conflict with the employee's statutory rights. The Gilmer court implied that one of the arguments for the Gardner-Denver decision against mandatory arbitration was the fear that unions would, as they can do with any grievance, sacrifice an individual employee's discrimination charge for the benefit of the bargaining unit as a whole. Because there was no union to horse trade Gilmer's rights away, the court found mandatory arbitration to be appropriate in the nonunion setting. Finally, unlike the one in Gardner-Denver, the arbitration clause in Gilmer was enforceable under the Federal Arbitration Act of 1925. ${ }^{3}$ However, one circuit (the Fourth) sees no such distinction, as explained in the accompanying article. ${ }^{4}-D . S . S$. and J.B.T.

\footnotetext{
${ }^{1} 111$ S.Ct. 1647 (1991).

2415 U.S. 36 (1974).

${ }^{3}$ U.S.C. Section 1.

${ }^{4}$ See: Austin v. Owens-Brockway Glass Container, 78 F.3d 875 (4th Cir. 1996)
} 


\section{Adjudication Is Expensive and Inefficient}

To file a discrimination lawsuit against an employer, employees must first file a charge of discrimination with either the Equal Employment Opportunity Commission (EEOC) or with a state or local agency that is authorized to investigate such claims. The agency with which an employee files a charge will investigate the allegation and try to settle the matter by having the employer remunerate or reinstate the employee. If the employer and employee cannot agree on a settlement, the agency determines whether there is cause to believe that discrimination occurred. If the agency finds no cause, the employee can either drop the case or request a right-to-sue letter, which enables the employee to file an action in federal or state court. If the agency finds cause, it may, depending on the agency (1) issue a right-to-sue letter, (2) set the case for trial before its own administrative adjudication process, or (3) become the employee's counsel and file an action in federal court on the claimant's behalf.

In establishing administrative procedures for handling employment-discrimination cases, the EEOC and the U.S. Congress attempted to develop a system that would provide employees with an agency to investigate all charges yet would not expose employers to the high costs associated with litigation. More than 30 years after its enactment, however, it is clear to us that the system is not accomplishing its goals. For example, the Civil Rights Act of 1991 made employment-discrimination claims more attractive to plaintiffs and their attorneys by allowing jury trials and providing for punitive and compensatory damages. ${ }^{1}$

Voluntary ADR. The EEOC has acknowledged the system's inefficiencies by creating a number of procedures to reduce its backlog of complaints and weed out frivolous cases. One such procedure is voluntary alternative dispute resolution. Unfortunately, the EEOC's call for a voluntary plan will not seriously affect employers or employees because, we propose, most parties will act strategically by using litigation as a bargaining tool.

In our view, the only cases where both parties are likely to arbitrate is where they both truly believe that they can prove their cases. We believe that this represents an insignificant number of claims. Moreover, we believe that in the bulk of cases either the employer or the employee knows she or he has a weak case or defense. We strongly believe, therefore, that both employees and employers would be better served by mandatory arbitration agreements.

For example, consider those employers who know that they have violated the law and those that acted in good faith and are innocent but cannot prove it for lack of good documentation and witnesses (i.e., they believe that they have "bad facts"). Such employers likely will not voluntarily submit their claims to arbitration. Such employers do not want a relatively quick assessment of damages against them. Instead, those employers can use the delay and discovery tactics that are part and parcel of federal-court litigation to force the aggrieved $\mathrm{cm}$ ployee to accepted a limited settlement. Likewise, employees who file frivolous cases will not be encouraged to arbitrate. They would be better off subjecting the employer to the potential costs of drawn-out litigation in hopes of receiving any settlement offer at all, not to mention a settlement offer that is larger than they could expect in arbitration.

Big settlements. In addition to increasing the number of claims filed, the current complaint procedures have increased the amount of settlements, despite the actual merits of the complaints. When damages consisted primarily of back pay, employees' damages were capped as soon as they found new employment that paid them as much or more than they had been earning in their previous positions. In such situations an employer could almost always settle the case for back pay only. ${ }^{2}$ Now, however, employees have an incentive to reject a settlement offer in the hope of receiving an even larger settlement.

Another problem created by the current system of adjudication is the emphasis on settling claims regardless of their merit or validity. Such a de facto severance system is a natural outgrowth of the practical realities associated with the current enforcement system. To file a charge of discrimination, employees must establish a prima facie case of discrimination. Establishing such a case is simple. Employees need only prove that (1) they are members of a protected class, (2) they were minimally qualified for the position, (3) they were mistreated by their employer, and (4) employees who do not belong to that protected class were not mistreated. ${ }^{3}$

Such employees do not have to provide any evidence of discrimination, they do not need an attorney, and they do not have to pay a filing fee. The EEOC accepts and investigates all charges. Moreover, some state agencies not only accept and investigate all charges, but they actually help employees "fit" their facts into the prima facie criteria. ${ }^{4}$ Thus, the de facto severance system exists because it is simple for an employee to file a charge of discrimination and it is costly for an employer to defend a charge.

Employers accused of discrimination are required to complete a questionnaire and provide the investigating agency with a statement of position. Responding to a discrimination charge may cost an employer thousands of dollars in attorneys' fees. If the case is not resolved at 
the agency level and is instead adjudicated in court, the employer's attorneys' fees may be astronomical. Additional employer costs include the loss of productivity of other employees involved in the case, adverse publicity, and, of course, liability. Because defending a discrimination charge can cost an employer hundreds of thousands of dollars, there is a strong incentive for employers to settle a case regardless of merit.

The current system also provides investigators with a strong incentive to settle cases. Some agencies evaluate the investigators by how many cases they close each quarter. For example, we were told by state officials that in 1994 the Pennsylvania Human Rights Commission required its investigators to close 12 cases per month.

It is standard operating procedure for some state investigators to attempt to settle a case without even discussing the case's merits or reviewing the file. Even employers who are outraged at the allegation may be convinced by their attorney and the investigator that it is in their best financial interest to pay the employee a nominal amount of money (and sometimes a substantial amount) instead of defending the case. When news of such settlements travels among employees, it is possible that the employer will be faced with numerous baseless claims from other employees also seeking de facto severance awards.

Under the current system claims are not investigated in a timely or comprehensive manner. One reason for the delays is that the EEOC's caseload has increased while the number of investigators has decreased. ${ }^{5}$

The negative effects of the system on both hospitality firms and employees is also evidenced by the number of "no cause" determinations made by investigators. In 1980 the EEOC found no cause in 28.5 percent of the 49,225 cases it closed. In 1992 the agency found no cause in 61 percent of the 68,366 cases it closed. Employers argue that the increase in the number of nocause findings results from an increase in the number of frivolous filings, while employee advocates point to a General Accounting Office study that found the EEOC failed to adequately investigate between 40 and 80 percent of the no-cause cases. ${ }^{6}$

This is not surprising since, as we said, the investigators' performance is often evaluated by the number of cases closed and because agencies are reluctant to find cause because such findings necessitate the allocation of increasingly scarce resources.?

Bad-actor employers and employees use the costs and delays of the system to their benefit. Investigators who push cases to close regardless of merit reinforce the bad actors' actions by threatening innocent employers with the costs of investigation and litigation, on the one hand, and employees with delays and the probability of no-cause findings, on the other. As a result, many employers settle these cases no matter what. Similarly, unemployed former employees with legitimate claims may choose a modest settlement today rather than the opportunity to be awarded more money sometime in the future.-D.S.S. and J,B.T.

${ }^{1}$ Prior to the Civil Rights Act of 1991 damages consisted of reinstatement, back pay, and attorneys' fees.

${ }^{2}$ While an employee could reject the settlement offer and continue the claim to obtain reinstatement, in fact few newly employed workers want to return to work for an employer that they have sued.

${ }^{3}$ McDonnell Douglas v. Green, 411 U.S. 792 (1973).

${ }^{4}$ The system contains an incentive that encourages this type of outcome. The federal government bases its funding of state agencies on the number of claims an agency handles. Consequently, some state agencies evaluate their intake officers by tracking the number of claims they receive. Intake officers are encouraged, therefore, to help create charges to develop a claim, even if they believe the law has not been violated.

${ }^{5}$ From 1989 through 1994 discrimination claims rose 46.7 percent and the number of investigators at the EEOC dropped by 13 percent. The combination of increased claims and fewer investigators results in extensive delays and, according to the General Accounting Office, an increase in the percentage of no-cause findings (see: Peter Eisler, "Waiting for Justice," USA Today, August 15, 1995, p. A1). Some cases are not investigated for over two years. At this writing [in 1997], state agencies and the EEOC have close to 200,000 open cases, an increase of 71.1 percent from 1990 Because the EEOC closed only 71,563 cases in 1994 (according to EEOC Enforcement Statistics, FY 1980-FY 1994), it seems certain that the delays will only worsen.

${ }^{6}$ Eisler, p. A1.

${ }^{7}$ An example of an agency that discourages cause findings is the Pennsylvania Human Rights Office in Pittsburgh. Investigators are encouraged to try to settle cases regardless of merit. If a case cannot be settled, however, it is nearly impossible for an investigator to "find cause." Findings of cause must be approved by the legal department. According to the investigators, their recommendations to find cause are rejected unless the employee's case is considered impossible to close otherwise. 
court to rule that the stock exchange's arbitration clause was enforceable under the FAA. Two questions were not answered by the court regarding the lawfulness of the mandatory-arbitration agreements, however. Those are: (1) Does the FAA exclude all employment contracts from its jurisdiction?, and (2) Does exclusion from the

\section{It is risky for employers to implement a mandatory- arbitration policy in those circuits where the courts have yet to rule on which employees can be covered.}

FAA's coverage prevent a compulsory-arbitration clause from being enforceable? The court's failure to answer those questions is why it is unclear whether compulsory-arbitration policies are enforceable in all jurisdictions. ${ }^{\text {? }}$

Excluding contracts. The first question centers on the interpretation of the exclusionary phase in the FAA's Section 1 that reads: "any other classification of worker engaged in interstate or foreign commerce." Some lower courts interpret this clause broadly and hold that it excludes from the FAA's coverage contracts between any employer and any employee. However, the majority of U.S Courts of Appeals holds that the exclusionary clause refers only to employees in the transportation industry. Under the latter interpretation, the FAA applies to all other employees such that an arbitration clause prevents all but a small class of employees from litigating their claims in federal court. The First, Second, Third, Fifth, Sixth, and Seventh circuits all narrowly interpret that exemption and hold that the FAA does, in fact, apply to the majority of employment contracts (excluding only those workers in the transportation industry). ${ }^{10}$

\footnotetext{
'The court's distinction that Gilmer's arbitration agreement was not with his employer seems odd when one examines the actual agreement. The agreement addresses disputes between the employee and employer. Thus, the fact that the contract was with the stock exchange and not the employer does not, it seems to us, affect the context of the agreement.

${ }^{10}$ See: Dickstein v. Dupont, 443 F.2d 783 (1st Cir. 1971); Erving v. The Virginia Squires Basketball Club, 468 F.2d 1064 (2 Cir. 1972); Tenney Engineering v. United Electrical R. \& M. Workers, 207 F.2d 450 (3rd Cir. 1953); Rojas v. TK Communications, Inc., 87 F.3d 745 (5th Cir. 1996); Aspuldh Tree Expert Co. v. Bates, 71 F.2d 592 (Gth Cir. 1995); and Miller Brewing Company v. Brewery Workers Local Union No. 9, 739 F.2d 1159 (7th Cir. 1984).
}

The Eighth, Ninth, Tenth, Eleventh, and D.C. circuits have not ruled on the meaning of the FAA's Section 1 exclusion. As such it would be risky for an employer governed by those circuits to implement an arbitration policy. ${ }^{11}$

The only court of appeals holding that follows the broad interpretation of the FAA's Section 1 is the Fourth Circuit's 1954 decision in United Electric Radio \& Machine Workers of America v. Miller Metal Products. ${ }^{12}$ The Miller holding may no longer be relevant, however, because of two more-recent cases. In Kropfelder $v$. Snap-On Tools Corporation the Fourth Circuit distinguished Miller by holding that it applied to collective-bargaining agreements only. ${ }^{13}$ The Kropfelder court then upheld a nonunion arbitration agreement.

Enforcing arbitration. The Fourth Circuit may also have answered the second question left open by the Gilmer decision, which is whether the FAA is relevant to the arbitration of discrimination claims. In Austin v. Owens-Brockway Glass Container the court limited the Miller decision and held that the FAA did not apply to labor disputes (in its circuit). Despite this holding, however, the court still upheld the enforceability of the arbitration clause by relying on a national labor-law policy encouraging arbitration, regardless of the FAA's applicability:

In deciding whether to enforce the arbitration provision in the collective bargaining agreement, we start with and rely on the well-recognized policy of federal labor law favoring the arbitration of labor disputes. $^{14}$

The Austin decision has been criticized because it ignores the fact that Gilmer did not overturn the Gardner-Denver decision and instead distinguished the case because of the union-nonunion distinction. Austin, however, does articulate the

\footnotetext{
"While there are district-court cases in those circuits that follow the interpretation of the majority of circuit courts, district courts are not bound by the precedent set in other circuits and, moreover, their decisions may be overturned by their circuit courts.

${ }^{12} 215$ F.2d 221 (4th Cir. 1954).

${ }^{13}$ Kropfelder $v$. Snap-On Tools Corporation, 859 F.Supp. 952 (D.Md. 1994)

${ }^{14}$ Austin at 879 .
} 
obvious point. The enforceability of a policy mandating the arbitration of a discrimination complaint should not be based on the applicability of a statute passed 40 years before Title VII. Instead, courts should follow the well-established practice of encouraging arbitration to settle disputes between employees and employers. Based on Austin, as well as a number of other cases, we believe that absent legislation to the contrary, arbitration will likely be formally extended to all employment contracts in the future, without regard to the FAA. ${ }^{15}$

\section{Minimum Requirements of Arbitration Policies}

Courts will enforce an arbitration policy only if it provides a fair process for adjudicating employees' statutory rights. In judging fairness, courts examine the policy's content, not its author. Thus, an employer cannot assure itself of surviving judicial scrutiny simply by allowing a neutral third party or even employees to help draft the arbitration agreement. Unfortunately, neither the U.S. Supreme Court nor Congress has expressly defined the criteria that, if met, would constitute a fair policy. This does not mean, however, that there is a dearth of authority as to what constitutes a fair policy. In arguing that particular arbitration systems are not fair, employees have focused on a number of different procedures that are inherent to every policy. The courts' holdings in response to such employee attacks provide a basis for establishing the criteria of what an enforceable policy must contain. It should be noted, however, that because the courts are reacting to complaints, as opposed to establishing criteria, the holdings are not always definitive and may not provide absolute guidance. Still, there is enough information to provide employers with the guidance necessary to draft a policy that will almost certainly be upheld.

In examining fairness, Gilmer and its progeny focus on the following five issues: (1) the method of delivering opinions, (2) the procedures for selecting fair and impartial arbitrators, (3) discovery, (4) the damages available, and (5) whether the agreement was entered into voluntarily and knowingly.

\footnotetext{
${ }^{15}$ For example, see: Central States Pension Fund v. Tank Transportation, 779 F.Supp. 947 (N.D.Ill. 1991).
}

Opinion procedures. The first issue, how the arbitrator's opinion should be delivered, is the simplest to address. In Gilmer the court noted that the stock exchange's procedures required written opinions. While the court did not hold that having written opinions is a requirement, it did imply that a policy should provide for them. Employers have a strong incentive to comply with this standard because, in addition to satisfying judicial review, written opinions will enable arbitration participants to study the outcomes of prior complaints. Such a study is vital when choosing an arbitrator and deciding whether to settle a case.

Selecting arbitrators. The selection of a fair and impartial arbitrator is a two-step process with requirements that are easily addressed. First, courts will not enforce a policy that does not allow for a fair and impartial third party to adjudicate the case. For example, in Canindin $v$. Renaissance Hotel Associates, the employer's arbitration policy allowed managers to select a committee to hear employer-employee disputes. ${ }^{16}$ The committee comprised two employees, two managers, and the general manager, who would act as a tie breaker. Because the adjudicators were selected by management (and the tie breaker was a manager), the court held that the policy was unfair and therefore did not require the employee

\section{Courts will enforce arbitration policies only if they provide a fair process for adjud- icating employees' statutory rights.}

to submit her claim to the arbitrators. Instead, the holding enabled the employee to file her claim in court.

Second, courts agree that the employee must be able to participate in the selection of the fair and impartial arbitrator. In Gilmer, the NYSE's procedures allowed the pool of arbitrators to be appointed by the stock exchange's director of arbitration, and both the exchange and the complainant had a say in the choice of arbitrator.

\footnotetext{
1650 Cal. App. 4th 676 (Cal. Ct. App. 1996).
} 


\section{Employees Can Always File Charges with the EEOC}

It should be noted that the court in Gilmer v. Interstate-Johnson Lane Corporation held that an arbitration clause cannot prevent an employee from filing a charge with the EEOC. ${ }^{1}$ That is, under Gilmer an arbitration clause can prevent employees from filing suit, but cannot prevent the EEOC from litigating their cases. ${ }^{2}$ Several conditions may prompt involvement by the EEOC. First, an arbitration decision need not have any legal standing with or effect on the EEOC. Thus, the EEOC may completely ignore an arbitrator's finding and issue a right-to-sue letter. Second, regardless of whether the EEOC gives any consideration to an arbitration decision, it may initiate a full investigation of a discrimination claim. Third, the agency may litigate on behalf of an employee or group of employees (i.e., a class action) if the agency believes that there is a relevant issue of law that should be decided by a court. However, since the EEOC litigates only one-half of one percent of the charges filed, arbitration agreements will almost always allow the employer and employee to avoid federal court.

The fact that employees can file cases with the EEOC is at the heart of a dispute filed with the $\mathrm{Na}$ tional Labor Relations Board (NLRB). Bentley's Luggage Corporation, a Florida employer, required all its employees to sign an agreement under which they agreed to arbitrate any employment dispute. In addition to its general waiver language, the policy specifically stated that employees could not file charges with any federal or state agency. Along with violating the Gilmer holding (which expressly stated that claims. may be filed with the EEOC), it seems obvious that federal and state agencies, such as the Occupational Safety and Health Administration, the Department of Labor, and the NLRB, would not look kindly on an agreement that effectively made them moot.

Not surprisingly, then, the NLRB issued a complaint to determine whether such an agreement violates the National Labor Relations Act. Bentley's employees settled with their employer, and the employer altered the agreement so that it now complies with Gilmer (that is, it allows employees to file charges with the NLRB regardless of the arbitration requirement).-D.S.S and J.B.T.

\footnotetext{
111 S. C. 1647 (1991),

${ }^{2}$ The rationale is that the EEOC is authorized to investigate any claims of employment discrimination regardless of whether an employee has waived such rights. Because most state agencies do not initiate lawsuits on behalf of complainants for discrimination cases, however, an arbitration clause should, according to this analysis, prevent discrimination claims.
}

Employee advocates criticized this policy because an employer representative established the pool of arbitrators, the pool almost always consisted of white men who were over 55 years of age, and the arbitrators were not trained in discrimination law. Despite those objections, the court accepted the system because, in choosing the arbitrator from the pool, each side was allowed one peremptory challenge and unlimited challenges for cause.

To avoid challenges and employee resistance based on selection of arbitrators, we suggest using the American Arbitration Association (AAA). This association has established pools of arbitrators who are impartial, trained in the subject, and represent a diverse population. The use of AAA for selection of the arbitrator would have satisfied the court in Canindin, for instance, and was expressly endorsed by a Texas district court. ${ }^{17}$

Level of discovery. Establishing the level of discovery is not as simple as setring forth how opinions shall be given and how arbitrators will be chosen. In Williams v. Katten, Muchin \& Zavis the Seventh Circuit upheld the AAA's discovery rules. ${ }^{18}$ Under those rules, the arbitrator may subpoena witnesses and documents either independently or on the request of parties. This level of discovery, which is minimal when compared to that of federal court, was acceptable to the Seventh Circuit. The U.S. Supreme Court has neither upheld nor rejected the AAA's discovery procedures. In Gilmer the court stated that parties choosing arbitration trade the procedures of federal court for the simplicity, informality, and experience of arbitration. Denying enforcement of a policy based on its lack of full-blown discovery would contradict the court's logic in this instance. Thus, we believe that parties have a choice of either following the AAA's discovery rules or (to be really safe) expanding discovery to the levels approaching those suggested in Gilmer (i.e., document production, information requests, depositions, and subpoenas). In making this decision it should be noted that in most cases discovery helps the plaintiff more than it does the employer. Presumably the employer knows

${ }^{17}$ See: Olson v. American Arbitration Association, Inc., 876 F.Supp. 850 (N.D. Tex. 1995).

${ }^{18}$ Williams v. Katten Muchin \& Zavis, 837 F. Supp. 1430; (N.D. IL1993). 
why it made a personnel-related decision and can find all of the relevant facts.

Assessing damages. Damages is another issue that presents the employer with both choices and risks. In Gilmer the arbitrator had authority to award the full damages available under the statute. ${ }^{19}$ The court further stated:

\section{By agreeing to arbitrate a statutory claim, a party does not forgo the substantive rights afforded by the statute; it only sub- mits to their resolution in arbitral rather than a judicial forum.}

This language implies that an arbitration policy cannot limit damages, and most lower courts agree. In fact, the majority of courts has held that an arbitrator can award punitive damages that are provided for by statutory law, even if the arbitration agreement prohibits such. For example, in Graham Oil Company v. Arco Products Company the Ninth Circuit refused to enforce an arbitration agreement because it eliminated provisions for punitive damages. ${ }^{20}$ However, some courts disagree with this analysis. In Barvarati v. Josphthal Lyon \& Ross, Inc., Chief Judge Richard Posner of the Seventh Circuit stated that parties to an arbitration agreement could stipulate that punitive damages not be awarded. ${ }^{21}$ Similarly, in Kinnebrew v. Gulf Insurance Company the U.S. District Court for the Northern District of Texas upheld an arbitration policy that eliminated punitive damages, attorneys' fees, and reinstatement. ${ }^{22}$ In this case, however, the court retained jurisdiction to examine statutory remedies to which the employee could be entitled.

Employers who wish to limit relief can attempt to do so. In some jurisdictions, like the Seventh Circuit, employers may be able to do so successfully. There are, however, two risks involved. First, the courts may not enforce the policy. Second, it is likely that employees will perceive a policy that limits damages as being unfair. As we explain in

\footnotetext{
${ }^{19}$ In age-discrimination cases under ADEA, damages consist of back pay, reinstatement, attorneys' fees, and liquidated damages. Liquidated damages are equal to the amount of back pay.

${ }^{20} 43$ F.2d 1244 (9th Cir. 1994).

${ }^{21} 28$ F. $2 d$ 704, 709 (7th Cir. 1994).

${ }^{22} 67$ FEP Cases 189, 190 (N. Tex. 1994).
}

a moment, the perception of being fair is, we believe, an essential component of the fifth issue that employers must address-that is, implementing a determination.

Voluntary agreements. Given that the current system for adjudicating claims is a bad one for both employers and employees, arbitration may be a beneficial alternative for both sides. To benefit everyone, though, we believe that an arbitration policy must be drafted and implemented in such a manner that employees will welcome the idea. Limiting damages, for example, will not be viewed favorably by employees. Instead, employees may view the policy as the employer's attempt to attack employees' rights. Such a view will sabotage the last requirement of a lawful arbitration policy, which is that the process must constitute the employees' willing and knowing waiver of their right to file a federal-court action.

In Gilmer the court stated that "mere inequality in bargaining power...is not a sufficient reason to hold that arbitration agreements are never enforceable in the employment context." ${ }^{23}$ The court then held that the waiver was voluntary because the employee was a sophisticated business person. Because this may not always be the

\section{One court refused to enforce an arbitration} agreement because it eliminated provisions for punitive damages.

case, and to avoid litigation, we believe that employers should implement procedures to ensure employees' full knowledge and understanding of the policy as a way to encourage employees' acceptance of the agreement.

Fairness and scope. Finally, to be enforceable an arbitration agreement must comply with certain standards regarding scope and fairness. The former conclusion is underscored by two cases, namely, Prudential Insurance Company of American v. Lai and Farrand v. Lutheran Brotherhood. ${ }^{24}$

\footnotetext{
${ }^{23}$ Gilmer at 1655.

${ }^{24}$ See: Prudential Insurance Company of American v. Lai, 42 F.3d 1299 (9th Cir. 1994); and Farrand v. Lutheran Brotherhood, 993 F.2d 1253 (7th Cir. 1993).
} 
In those two cases, the Ninth and Seventh circuits held that generic arbitration clauses that did not explicitly state that they covered all employment disputes were not specific enough to provide employees with notice that they were bound to arbitrate Title VII claims and agediscrimination claims (under the Age Discrimi-

\section{Employees should be asked to help craft} an arbitration agreement.

nation in Employment Act). Complying with the notice requirements set forth in Lai and Farrand is relatively simple. The policy must explicitly state that all employee disputes, including allegations of discrimination, breach of contract, and other statutory or common-law claims, will be submitted to arbitration.

Complying with the fairness standard is not simple, however. The Gilmer court analyzed the New York Stock Exchange's agreement and found it fair for a number of reasons. The court did not, however, expressly state what a policy must include to survive judicial review. Moreover, we believe that surviving judicial review is not the only standard that employers should strive to meet. Instead, an arbitration policy should be regarded as something that will benefit both the employer and the employees.

\section{Implementing an Arbitration Policy}

Employers should first communicate to employees the employer's intention to adopt an arbitration agreement. Employees must clearly understand the implications of such a policy and should have an opportunity to discuss the effects of the policy's provisions on their employment. For example, employees should be informed that a mandatory-arbitration policy does not preclude EEOC involvement in a complaint (and they can also be forewarned about the difficulties associated with the EEOC's investigation and enforcement procedures). Failure to give employees an adequate opportunity to discuss and ask questions about the reasons for the arbitration policy can have a profoundly negative impact on the employee-employer relationship.

\section{Legislative Developments}

Despite the acceptance of arbitration by federal courts legislation was pending in both the U.S. House of Representatives and the Senate to ban so-called Gilmer agreements. The identical bills were sponsored by Senator Russell Feingold and Representatives Patricia Schroeder and Edward Markey. The Senate bill, which was entitled the Civil Rights Procedures Protection Act of 1996, would prohibit arbitration unless it was agreed to by both parties at the time the case was ripe. Feingold and Schroeder drafted similar legislation in 1993, 1994, and 1995. [As of our original writing, however], those bills have never come close to being enacted, perhaps because they seem ill conceived. According to the Markey staff member who spoke with us and is assigned to answer questions regarding this bill, the congressman's objection to arbitration is based in large part on the findings of studies regarding the age, gender, and ethnicity of securities-industry arbitrators. According to that staff member, such arbitrators are almost exclusively white men who are at least 60 years old. We argue that it is unwise to propose legislation banning an entire system because of one aspect that could easily be corrected.-D.S.S. and J.B.T.

Second, employees should be asked to help craft the arbitration agreement. Arbitration agreements represent more than a legally binding employment policy. They involve a "psychological contract" that forms a basis of trust and unwritten expectations between employees and employers. ${ }^{25}$ Such expectations may be associated with employees' job-related concerns such as workload, as well as intangible matters such as whether the employees feel "taken care of" by the employer. The form and perceived fairness of psychological contracts have an effect on employees' perceptions and actions. For example, some argue that violations of a psychological contract may create so much frustration that an individual will leave the organization. ${ }^{26}$ As such, involvement from those who will be affected by the agreement is critical. Getting line and managerial employees involved in the development process is a sure way to build support for the agreement.

${ }^{25}$ D. Rousseau, Psychological Contracts in Organizations (Thousand Oaks, CA: Sage Publications, 1995).

${ }^{26}$ E.H. Schein, Organizational Psychology, 3rd. ed. (Englewood Cliffs, NJ: Prentice-Hall, 1980). 
Finally, once the agreement is completed, its provisions should be introduced through company-wide training programs. This is particularly true for new employees, who undoubtedly have preconceived ideas about the organization and their job. It is critical that orientation programs incorporate all pertinent information from the arbitration agreement, especially as the socialization and orientation process itself has been shown to have a profound effect on job performance and work attitudes. ${ }^{27}$

\section{Call for Further Inquiry}

Some initial research has shown that replacing litigation with arbitration will make the adjudication process less expensive and less time consuming. ${ }^{28}$ However, a number of issues have yet to be examined. For example, there are few data on whether arbitrators are more or less apt than that the courts are to find for plaintiffs and award large damages. It is also unknown whether the implementation of an arbitration policy will increase or decrease the number of claims that are filed. If the process is perceived as fair, it is possible that the number of complaints will decrease, since employees' perceptions of their employers' fairness may discourage the employees from filing grievances. Another issue for consideration is the effect of mandatory arbitration on management-employee relations. If employees believe that an arbitration agreement provides an efficient mechanism for resolving conflict, and if they believe that the policy is fair and just, it is likely that they will feel a commitment to their organization and will therefore be less likely to leave it. Rigorous field studies that examine the influence of such agreements on these and other variables are required to determine the utility of arbitration agreements.

\footnotetext{
${ }^{27}$ J.P. Wanous, “Tell It Like It Is at Realistic Job Review," Personnel, July-August 1975, p. 54.

${ }^{28}$ W.M. Howard, "Arbitrating Claims of Employment Discrimination," Dispute Resolution Journal, OctoberDecember 1995, pp. 40-50.
}
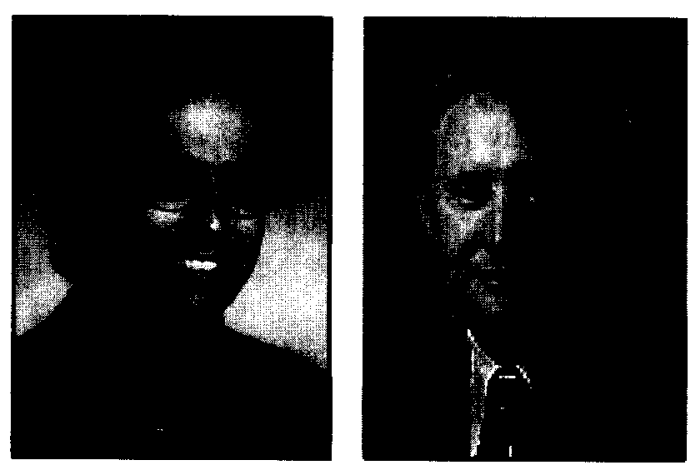

David S. Sherwyn, J.D. (above, left), is an assistant professor of law at the Cornell University School of Hotel Administration, where J. Bruce Tracey, Ph.D. (above, right), is an associate professor of management.

(C) 2001, Cornell University. 